\title{
Bemisia tabaci, Brevicoryne brassicae and Thrips tabaci abundance on Brassica oleracea var. acephala
}

\author{
Germano Leão Demolin Leite ${ }^{(1)}$, Marcelo Picanço(2), Gulab Newandram Jham ${ }^{(3)}$ \\ and Márcio Dionízio Moreira(2)
}

\begin{abstract}
(1)Universidade Federal de Minas Gerais, Núcleo de Ciências Agrárias, Dep. de Agropecuária, Caixa Postal 135, CEP $39404-006$ Montes Claros, MG, Brazil. E-mail: gldleite@nca.ufmg.br (2)Universidade Federal de Viçosa (UFV), Dep. de Biologia animal, CEP $36571-000$ Viçosa, MG, Brazil. E-mail: picanco@mail.ufv.br (3)UFV, Dep. de Química. E-mail: gulab@mail.ufv.br
\end{abstract}

\begin{abstract}
Kale Brassica oleracea var. acephala is attacked by whitefly Bemisia tabaci, aphid Brevicoryne brassicae and Thrips tabaci. One of the main reasons for extensive insecticide application is the lack of information about factors that control insect population. The objectives of this study were to investigate the relationships between predators and parasitoids, organic compound leaves, levels of leaf nitrogen and potassium, total rainfall, relative humidity, sunlight and median temperature on the abundance of whitefly, aphid, and thrips in kale genotype "Talo Roxo". The beating tray method, direct counting and magnifying lens were used to estimate the number of these pests, predators and parasitoids. Median temperature, sunlight and relative humidity correlated to the amount of leaf nonacosane, which in turn was associated with aphids population increase. A tendency in the reduction of aphids and thrips populations with increase in total rainfall was observed. The whitefly can be a harmful pest in kale producing regions of higher temperature and smaller rainfall. In regions which present moderate temperature, where there is a high incidence of aphids, genotype with low leaf wax content should be chosen. Natural enemies, especially the parasitoid Adialytus spp., can control agents of the aphids population in kale.
\end{abstract}

Index terms: population dynamics, nonacosane, climatic factors, Braconidae.

\section{Abundância de Bemisia tabaci, Brevicoryne brassicaee Thrips tabaci em Brassica oleracea var. acephala}

\begin{abstract}
Resumo - A couve, Brassica oleracea var. acephala, é atacada por mosca-branca Bemisia tabaci, pulgão Brevicoryne brassicae e tripes Thrips tabaci. Uma das principais razões para o uso intensivo de inseticidas é a falta de informação sobre os fatores que controlam a população de insetos. O objetivo deste estudo foi investigar as relações entre predadores e parasitóides, compostos orgânicos foliares, níveis foliares de nitrogênio e de potássio, pluviosidade total, umidade relativa, insolação e temperatura média na abundância da mosca-branca, pulgões e tripes em couve genótipo Talo Roxo. Foi usado o método da batida em bandeja, contagem direta e lupas de aumento para estimar o número dessas pragas, de predadores e de parasitóides. A temperatura média, insolação e umidade relativa correlacionaram com nonacosano foliar que, por sua vez, esteve associado com o aumento populacional de pulgões. Foi observada uma tendência na redução de pulgões e de tripes com o aumento da pluviosidade total. A mosca-branca pode ser uma praga prejudicial em regiões produtoras de couve de maior temperatura e de menor pluviosidade. Em regiões onde se tem maior incidência de pulgões (regiões de temperatura moderada) deve-se escolher um genótipo com baixo conteúdo foliar de cera. Inimigos naturais, especialmente o parasitóide Adialytus spp., podem ser agentes de controle da população de pulgões em couve.
\end{abstract}

Termos para indexação: dinâmica populacional, nonacosano, fatores climáticos, Braconidae.

\section{Introduction}

Kale Brassica oleracea L. var. acephala, cultivated in several countries, is attacked by several pests such as whitefly Bemisia tabaci (Genn.) (Homoptera: Aleyrodidade), aphid Brevicoryne brassicae (L.) (Homoptera: Aphididae), and Thrips tabaci Lind. (Thysanoptera: Thripidae) (Filgueira, 2000). These insects debilitate the kale plants by sucking the sap and introducing toxins into the plant's vascular system, coating the leaf with honey dew that facilitates the growth of sooty mold fungi, producing a white streaking disorder, leaf chlorosis foliar and leaf wrinkling.

In Brazil, insects attacking kale are controlled by blanket spraying with foliar insecticides. The frequency of insecticide applications is determined by the degree of damage, which is heavily influenced by cosmetic considerations (Leite et al., 1996). One of the main 
reasons for extensive insecticide application is the lack of information about factors that control insect population. Such information could facilitate the prediction of insect attack, which in turn could reduce economic losses.

Several factors such as climatic conditions, crop fertility status, natural enemies, and leaf organic compounds can influence insect population on plants (Horowitz, 1986; Leite et al., 1996; Gonçalves, 1997; Eigenbrode \& Pillai, 1998; Hooks et al., 1998). However, these factors have been little studied in kale.

The objectives of this study were to correlate abundance of natural enemies, leaf organic compounds, levels of $\mathrm{N}$ and $\mathrm{K}$ in leaves, total rainfall, relative humidity, sunlight and median temperature with the abundance of B. tabaci, B. brassicae and T. tabaci attack in kale, under field conditions.

\section{Material and Methods}

This experiment was conducted using two kale plantations of Brassica oleraceae L. var. acephala genotype "Talo Roxo" in Viçosa, Minas Gerais State, Brazil. The first kale plantation was evaluated from March (30 days old at evaluation time) to May, 1999 and the second between August (15 days old at evaluation time) and November, 1999 and planted in the same area.

Kale plantation comprehended 3,000 plants spaced $0.5 \mathrm{~m}$ apart within rows and $1.0 \mathrm{~m}$ between rows. The seven periphery rows and the first twelve plants on each end of the row formed the outer border and the remaining planting was the sampling area. Cultural practices utilized in this study have been described (Filgueira, 2000) and the plants were not sprayed with pesticides. The soil type of the area is "Podzólico Vermelho-Amarelo distrófico fase Terraço", according to the Brazilian classification (Resende et al., 1988), similar to the Paleudult of the American classification (USDA, 2003). This soil is poor in nutrients with moderate depth and low water permeability. It was used $2.5 \mathrm{~L} \mathrm{plant}^{-1}$ of organic fertilization and $200 \mathrm{~g} \mathrm{plant}^{-1}$ of 4-14-8 [nitrogen, phosphorous $\left(\mathrm{P}_{2} \mathrm{O}_{5}\right)$ and potassium $\left(\mathrm{K}_{2} \mathrm{O}\right)$ ], respectively.

Beating tray method (Miranda et al., 1998) was used to estimate weekly (9h AM) the number of adult B. tabaci, T. tabaci, predators and parasitoids and direct counting for adults and nymphs $B$. brassicae present in the first expanded leaf form from each ten plant's apex/ plantation. Nymphal B. tabaci parasitism index in the kale plant was evaluated weekly with 40x magnifying lens. One expanded leaf from the plant's apex of each ten plants/plantation was collected, conditioned in transparent white plastic bags, sealed and transported to the laboratory where counts were performed. For each sample, 18 fields (area of one field $=0.60 \mathrm{~mm}^{2}$ ) in the median part, equidistant between the median vein and the margin, were analyzed.

To identify organic compounds soluble in hexane, fully expanded leaves from apex of 12 kale plants/plantation were obtained monthly. The leaves were collected and placed in plastic bags, sealed, transported to the laboratory and $10 \mathrm{~g}$ of leaves were cut with scissors and immersed in $100 \mathrm{~mL}$ of bidistilled hexane for 24 hours. The hexane extract was dehydrated with anhydrous $\mathrm{Na}_{2} \mathrm{SO}_{4}$, evaporated to dryness at $30^{\circ} \mathrm{C}$ in a rotatory evaporator, sealed in nitrogen and stored in a freezer until analysis. Three evaluations were made for each monthly collection of the two plantations. The hexane extracts were analyzed by gas chromatography/ mass spectrometry (GC/MS) (Shimadzu, Model QP 5000) with an auto sampler, a computer based system to accumulate data and a mass spectral database (John Wiley) with 160,000 compounds.

The analyses were conducted using the following conditions: initial oven temperature of $33^{\circ} \mathrm{C}$ was programmed to $80^{\circ} \mathrm{C}$ at $20^{\circ} \mathrm{C} \mathrm{min}-1$ and finally to $250^{\circ} \mathrm{C}$ at $5^{\circ} \mathrm{C} \mathrm{min}^{-1}$. The injector and transfer line temperatures were maintained at $180^{\circ} \mathrm{C}$ and $280^{\circ} \mathrm{C}$, respectively. The split ratio was five and Helium was the carrier gas. The mass spectrometer was scanned between 40 and $550 \mathrm{amu}$. Peaks in the hexane were identified by the mass spectral database using similarity index (SI). Only peaks with SI $>90 \%$ were considered as positive identifications. Quantification was carried out by the external standard method by gas chromatography (Shimadzu, Model 17-A) equipped with a FID, an autosampler using the following conditions: initial oven temperature of $60^{\circ} \mathrm{C}$ was raised to $270^{\circ} \mathrm{C}$ at $10^{\circ} \mathrm{C} \mathrm{min}{ }^{-1}$ and held at this temperature for $10 \mathrm{~min}$. The injector and detector temperatures were $260^{\circ} \mathrm{C}$ and $280^{\circ} \mathrm{C}$, respectively. The split ratio was eight and nitrogen was the carrier gas. All analyses (GC/MS and GC) were carried on a DB 1 fused capillary column $(30 \mathrm{~m} \mathrm{x}$ $0.25 \mathrm{~mm}$ and film thickness of $0.25 \mathrm{~mm}$ ). Nonacosane was obtained from Aldrich and was specified to be $99 \%$ pure.

For determination of leaf $\mathrm{N}$ and $\mathrm{K}$, an expanded leaf from the apex of each of 12 plants/plantation was collected monthly, and taken to the laboratory. The leaves 
were placed in Kraft paper bags, dried in a forced air circulation oven at $67^{\circ} \mathrm{C}$ for three days and ground in a Wiley mill (20 mesh). The K was determined with flame photometer, and $\mathrm{N}$ was analyzed by the Nessler method. Three evaluations were made for each monthly collection of the two plantations.

Viçosa's climatic data [median temperature ((minimum + maximum)/2), sunlight, total rainfall and relative humidity] were collected daily, obtained by "Estação Climatológica Principal" of Universidade Federal de Viçosa (UFV) (INEMET/5DISME/UFV) during the experiment.

Data were submitted to simple or multiple regression analysis $(\mathrm{P}<0.05)$ and paramethers utilized in the equations were significant $(\mathrm{P}<0.05)$ for selection of variables by "Stepwise" method.

\section{Results and Discussion}

Several peaks were recorded on GC/MS analysis of the hexane extracts but only nonacosane was identified by the mass spectra database due to a similarity index of $93 \%$. The presence of nonacosane was confirmed with standard and quantified by GC. Among the factors studied, sunlight $(\mathrm{X})$, median temperature $(\mathrm{Z})$ and relative humidity (W) correlated with nonacosane $(\mathrm{y}=101.110$ $\left.+3.644 \mathrm{X}-0.905 \mathrm{Z}-1.185 \mathrm{~W}, \mathrm{R}^{2}=0.99, \mathrm{P}<0.0001\right)$. The leaf nonacosane in kale, a principal component of wax in the Brassicaceae (Eigenbrode \& Pillai, 1998), has been related to plant adoption to hydric stress (Hull et al., 1975).

In the first kale plantation, increases in the B. brassicae population and nonacosane concentration ( $\mathrm{mg} \mathrm{g}^{-1}$ of fresh leaf weight) were observed from March to May, however, in the second kale plantation, a decrease in the aphids and nonacosane were observed from August to November (Figure 1). Increases in median temperature and relative humidity and decrease in nonacosane content were accompanied by a decrease in B. brassicae density (Figure 2). Nitrogen and $\mathrm{K}$ content decreased from March to April and had a peak in September (Figure 1). Total rainfall and sunlight did not correlate with B. brassicae (Figures 3).

Kale genotypes which possess high wax levels have been reported to be more susceptible to B. brassicae attack but more resistant to Myzus persicae (Sulzer) (Homoptera: Aphididae) (Paula et al., 1995; Leite et al.,
1996). However, no relationship between nonacosane and B. tabaci and T. tabaci was observed in kale. The general accepted hypothesis is that the wax components rarely detain herbivore attack and more commonly stimulate them (Woodhead \& Chapman, 1986), such as observed here.

The B. tabaci population showed a peak in April (first plantation) and in the second kale plantation, a decrease in the whitefly was observed from August to October (Figure 1). The population of T. tabaci, which was small in the first and high in the second plantation, showed a peak in October (Figure 1). Leaf organic compounds and nutritional leaves characteristics did not correlate with these pests, and the climatic data did not correlate with T. tabaci. However, total rainfall (X), median temperature $(\mathrm{Z})$ and relative humidity $(\mathrm{W})$ correlated with B. tabaci $(\mathrm{y}=-2.324-0.001 \mathrm{X}+0.022 \mathrm{Z}+0.028 \mathrm{~W}$, $\left.\mathrm{R}^{2}=0.90, \mathrm{P}<0.05\right)$.

The $B$. tabaci population was negatively affected by total rainfall, while negative correlation of $B$. brassicae and T. tabaci population with total rainfall was non significant (Figures 1 and 3). Bemisia brassicae population tended to decrease while that of $B$. tabaci and T. tabaci populations tended to increase as the median temperature increased. Increases in temperature favor B. tabaci and T. tabaci populations while heavy rain and high humidity are deleterious to these insects (Horowitz, 1986; Lorini \& Dezordi, 1990; Horowitz et al., 1994; Gonçalves, 1997; Leite et al., 2002a). On the other hand, high temperatures and rainfall are important mortality factors of aphids in field (Nakata, 1995; Cividanes, 2002; Cividanes \& Santos, 2003).

High $\mathrm{N}$ levels have been associated with whitefly, aphids and thrips infestation on Lycopersicon esculentum, Cucurbita maxima and Gossypium hirsutum (Leite et al., 1998, 2002b; Brodbeck et al., 2001; Cisneros \& Godfrey, 2001; Nevo \& Coll, 2001) and $\mathrm{N}$ can be a key factor for increasing number of aphids in G. hirsutum (Cisneros \& Godfrey, 2001). Leite et al. (2002b) noted no effect of $\mathrm{N}$ and $\mathrm{K}$ foliar on whitefly population in Solanum gilo. However, the increase on level of $\mathrm{K}$ is associated to the reduction of pests because this chemical element is included in the synthesis of the RNA polimerase (Marschner, 1995). The absence of effect of $\mathrm{N}$ and $\mathrm{K}$ levels on kale leaves attacked by B. tabaci, B. brassicae and T. tabaci might 
be ascribed to low variations on levels of these compounds on leaves of this plant during the experimental period.
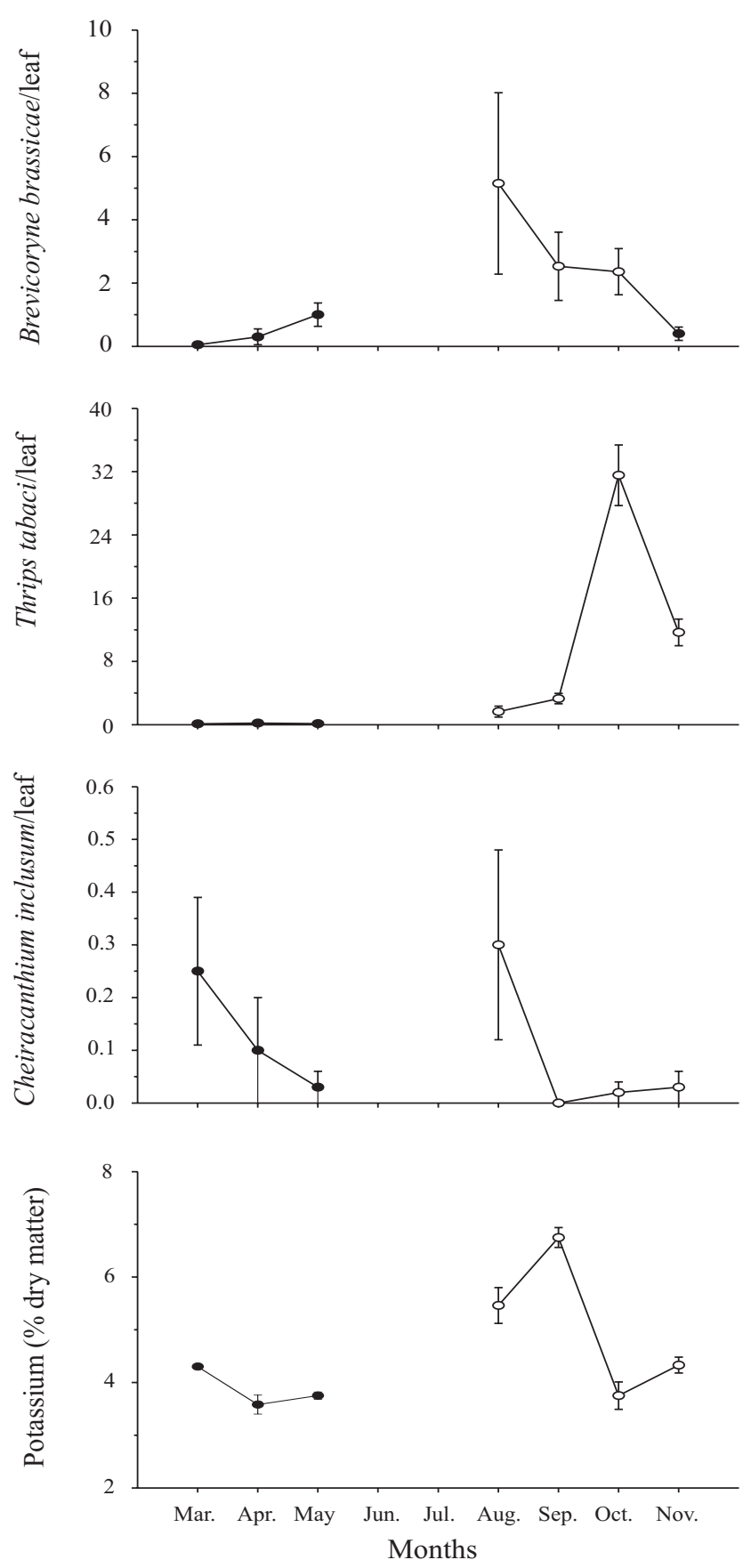

The peak population of parasitoid Adyalitus spp. (Hymenoptera: Braconidae) was in October and the
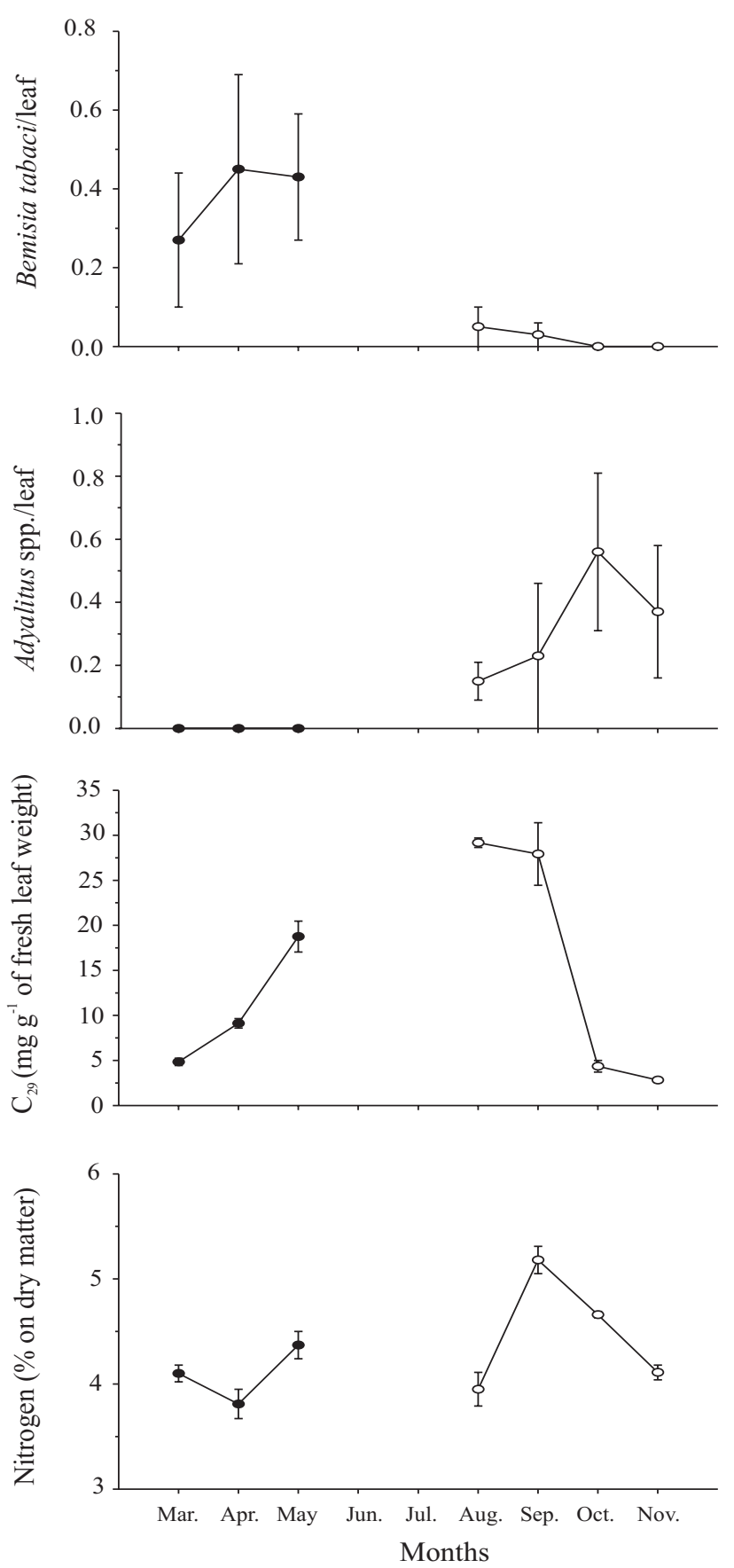

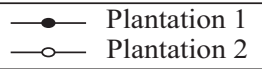

Figure 1. Fluctuations in populations of Brevicoryne brassicae (adults + nymphs), Bemisia tabaci (adults), Thrips tabaci (adults + nymphs), Adialytus spp. (adults), Cheiracanthium inclusum (adults + young), nonacosane content $\left(\mathrm{C}_{29}\right)$, potassium and nitrogen content in kale. The symbols represent the average of 40 leaves for each insect population, and three evaluations for nonacosane, potassium and nitrogen content. The vertical bars indicate standards errors of the mean. 
population of spider Cheiracanthium inclusum (Hentz) (Miturgidae) decreased in both kale plantations with increasing plant age (Figure 1). Positive correlation was observed between Adyalitus spp. and B. brassicae (Figure 2). However, no significant correlations between Encarsia sp. (Hymenoptera: Aphelinidae) $\left(0.01 \pm 0.01\right.$ leaf $\left.^{-1}\right)$, spider and Aelothripidae (Thysanoptera) $\left(0.01 \pm 0.01 \mathrm{leaf}^{-1}\right)$ with population of
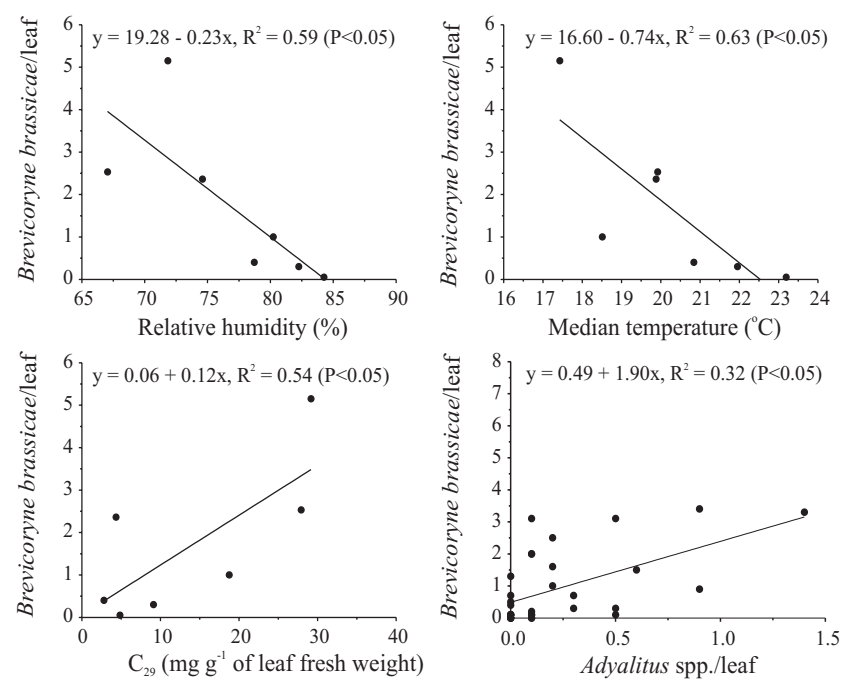

Figure 2. Effect of relative humidity, median temperature, nonacosane content $\left(\mathrm{C}_{29}\right)$ and Adialytus spp. (adults) on the Brevicoryne brassicae (adults + nymphs). The symbols represent the average of 40 leaves.

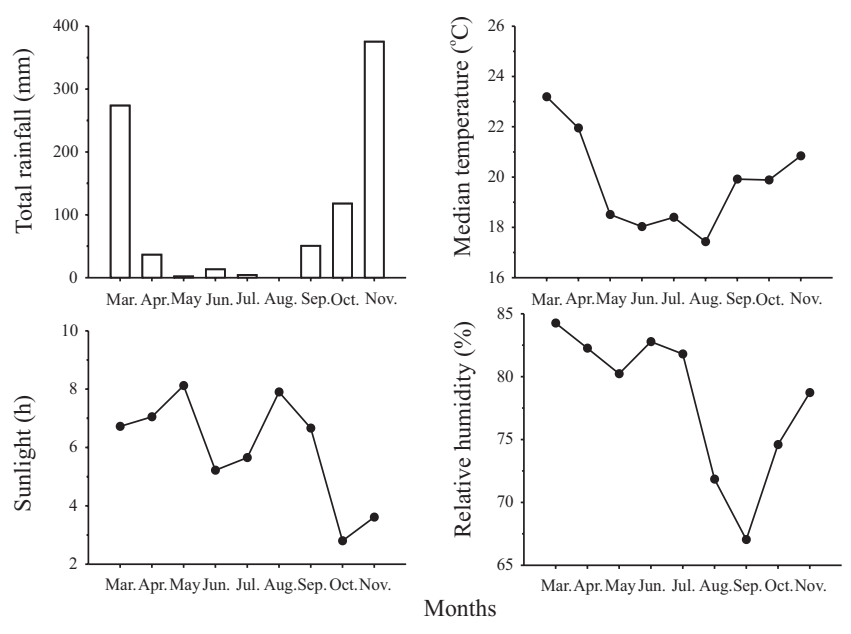

Figure 3. Total rainfall distribution, median temperature $(($ minimum + maximum $) / 2)$, sunlight and relative humidity during experimental period in Viçosa. The symbols represent the rainfall accumulated and the average of the median temperature, sunlight and relative humidity of 30 days.
B. tabaci, B. brassicae and T. tabaci were detected as well as no parasitized-infected $B$. tabaci nymphs were found.

The parasite Adialytus spp. appeared to be the limiting factor for population increase of $B$. Brassicae, such as observed by Hooks et al. (1998) with the Aphis gossypii (Glover) (Homoptera: Aphididae) population in zucchini Cucurbita pepo L. Low densities of the remaining natural enemies studied were observed and appeared to be the probable factors responsible for the lack of correlations with whitefly, thrips and aphid populations in kale.

\section{Conclusions}

1. Bemisia tabaci can be a harmful pest in kale producing regions of higher temperature and smaller rainfall.

2. In regions where there is a high incidence of B. brassicae (regions of moderate temperature), one should choose genotype with low leaf wax content.

3. Natural enemies, especially the parasitoid Adialytus spp., can be important controlling agents of the $B$. brassicae population in kale.

\section{Acknowledgements}

To the Brazilian government agencies "Coordenação de Aperfeiçoamento de Pessoal de Nível Superior" (Capes), "Conselho Nacional de Desenvolvimento Científico e Tecnológico" (CNPq) and "Fundação de Amparo à Pesquisa do Estado de Minas Gerais" (Fapemig), for financial support; to the taxonomists Drs. Antonio D. Brescovit and Celso Oliveira Azevedo, for the identification of insects; to Emater extension worker, José Alexandre de Moura Malfacini.

\section{References}

BRODBECK, B.V.; STAVISKY, J.; FUNDERBURK, J.E.; ANDERSEN, P.C.; OLSON, S.M. Flower nitrogen status and populations of Frankliniella occidentalis feeding on Lycopersicon esculentum. Entomologia Experimentali et Applicata, v.99, p.165172,2001

CISNEROS, J.J.; GODFREY, L.D. Midseason pest status of the cotton aphid (Homoptera: Aphididae) in California cotton: is nitrogen a key factor? Environmental Entomology, v.30, p.501-510, 2001.

CIVIDANES, F.J. Tabela de vida de Brevicoryne brassicae (L.) (Hemiptera: Aphididae) em condições de campo. Neotropical Entomology, v.31, p.419-427, 2002.

CIVIDANES, F.J.; SANTOS, D.M.M. Flutuação populacional e distribuição vertical de Brevicoryne brassicae (L.) (Hemiptera: Aphididae) em couve. Bragantia, v.62, p.61-67, 2003. 
EIGENBRODE, S.D.; PILLAI, S.K. Neonate Plutella xylostella responses to surface wax components of a resistant cabbage (Brassica oleracea). Journal of Chemical Ecology, v.24, p.1611-1627, 1998. FILGUEIRA, F.A.R. Novo manual de olericultura. Viçosa: UFV, 2000. 402p.

GONÇALVES, P.A.S. Flutuação populacional de tripes, Thrips tabaci Lind., em cebola em Ituporanga, Santa Catarina. Anais da Sociedade Entomológica do Brasil, v.26, p.365-369, 1997.

HOOKS, C.R.R.; VALENZUELA, H.R.; DEFRANK, J. Incidence of pests and arthropod natural enemies in zucchini grown with living mulches. Agriculture, Ecosystems and Environment, v.69, p.217231,1998

HOROWITZ, A.R. Population dynamics of Bemisia tabaci (Gennadius): with special emphasis on cotton fields. Agriculture, Ecosystems and Environment, v.17, p.37-47, 1986.

HOROWITZ, A.R.; FORER, G.; ISHAAYA, I. Managing resistance in Bemisia tabaci in Israel with emphasis on cotton. Pesticide Science, v.42, p.113-122, 1994.

HULL, H.M.; MORTON, H.L.; WHARRIE, J.R. Environmental influences on cuticle development and resultant foliar penetration. Botanical Review, v.41, p.421-452, 1975.

LEITE, G.L.D.; PICANÇO, M.; AZEVEDO, A.A.; GUSMÃO, M.R. Factores que influenciam as populações de artrópodes em moranga (Cucurbita maxima var. IAC-100). Agronomia Lusitana, v.50, p.153-159, 2002b.

LEITE, G.L.D.; PICANÇO, M.; BASTOS, C.S.; ARAÚJO, J.M.; AZEVEDO, A.A. Resistência de clones de couve comum ao pulgão verde. Horticultura Brasileira, v.14, p.178-181, 1996.

LEITE, G.L.D.; PICANÇO, M.; ZANUNCIO, J.C.; GONRING, A.H.R. Effect of fertilization levels, age and canopy height of Lycopersicon spp. on attack rate of Bemisia tabaci (Homoptera: Aleyrodidae). Agronomia Lusitana, v.46, p.53-60, 1998.

LEITE, G.L.D.; PICANÇO, M.; ZANUNCIO, J.C.; MOREIRA, M.D.; PEREIRA, P.R. Fatores que influenciam o ataque de mosca- branca em jiloeiro. Pesquisa Agropecuária Brasileira, v.37, p.10331037, 2002a.

LORINI, I.; DEZORDI, J. Flutuação populacional de Thrips tabaci Lindeman, 1888 (Thysanoptera: Thipidae) na cultura da cebola. Anais da Sociedade Entomológica do Brasil, v.19, p.361-365, 1990.

MARSCHNER, H. Mineral nutrition of higher plants. London: Academic Press, 1995. 889p.

MIRANDA, M.M.M.; PICANÇO, M.; LEITE, G.L.D.; ZANUNCIO, J.C.; CLERCQ, P. Sampling and non-action levels for predators and parasitoids of virus vectors and leaf miners of tomato plants in Brazil. Mededelingen Faculteit Landbouwwetenschappen Universiteit Gent, v.63, p.519-523, 1998.

NAKATA, T. Population fluctuations of aphids and their natural enemies on potato in Hokkaido, Japan. Applied Entomology and Zoology, v.30, p.129-138, 1995.

NEVO, E.; COLL, M. Effect of nitrogen fertilization on Aphis gossypii (Homoptera: Aphididae): variation in size, color and reproduction. Journal of Economic Entomology, vol.94, p.27-32, 2001.

PAULA, S.V.; PICANÇO, M.; KOGA, F.H.; MORÃES, J.C. Resistência de sete clones de couve comum à Brevicoryne brassicae (L.) (Homoptera: Aphididae). Anais da Sociedade Entomológica do Brasil, v.24, p.99-104, 1995.

RESEnde, M.; CURI, N.; SANTANA, D.P. Pedologia e fertilidade dos solos: interações e aplicações. Brasília: MEC, 1988. $83 \mathrm{p}$.

USDA. Keys to Soil Taxonomy. Washington: USDA, 2003. 332p.

WOODHEAD, S.; CHAPMAN, R.F. Insect behaviour and the chemistry of plant surface waxes. In: JUNIPER, B.E.; SOUTHWOOD, T.R.E. (Ed.). Insect and the plant surface. London: Edward Arnold, 1986. p.123-135.

$\overline{\text { Received on February 17, } 2004 \text { and accepted on November 18, } 2004}$ 